\title{
Fluxes of nitrates between snow surfaces and the atmosphere in the European high Arctic
}

\author{
H. J. Beine ${ }^{1}$, F. Dominé ${ }^{2}$, A. Ianniello ${ }^{1}$, M. Nardino ${ }^{3}$, I. Allegrini ${ }^{1}$, K. Teinilä ${ }^{4}$, and R. Hillamo ${ }^{4}$ \\ ${ }^{1}$ C.N.R. - IIA, Roma, Italy \\ ${ }^{2}$ CNRS - LGGE, Grenoble, France \\ ${ }^{3}$ C.N.R. - ISAC, Bologna, Italy \\ ${ }^{4}$ FMI - Air Quality Research, Helsinki, Finland
}

Received: 24 October 2002 - Published in Atmos. Chem. Phys. Discuss.: 6 January 2003

Revised: 7 March 2003 - Accepted: 14 March 2003 - Published: 27 March 2003

\begin{abstract}
Measurements of atmospheric and snow mixing ratios of nitrates and nitrites and their fluxes above the snow surface were made during two intensive campaigns during spring time 2001 at Ny-Ålesund, Svalbard as part of the EU project "The NItrogen Cycle and Effects on the oxidation of atmospheric trace species at high latitudes" (NICE).

At this coastal site close to the unseasonably unfrozen fjord, of the measured nitrogen species, only $\mathrm{HNO}_{3}$ showed a significant flux on to the snow surface; a mean deposition of $-8.7 \mathrm{nmol} \mathrm{h}^{-1} \mathrm{~m}^{-2}$ was observed in late April / early May 2001. These fluxes may be due to the reaction of $\mathrm{HNO}_{3}$ with sea salt, and especially $\mathrm{NaCl}$, or may be simply uptake of $\mathrm{HNO}_{3}$ by ice, which is alkaline because of the sea salt in our marine environment. During snowfall periods dry deposition of $\mathrm{HNO}_{3}$ may contribute up to $10 \%$ of the $\mathrm{N}$ budget in the snow; however, the main source for $\mathrm{N}$ is wet deposition in falling snow.
\end{abstract}

The surface snow at Ny-Ålesund showed very complex stratigraphy; the $\mathrm{NO}_{3}^{-}$mixing ratio in snow varied between 65 and $520 \mathrm{ng} \mathrm{g}^{-1}$, the total $\mathrm{NO}_{3}^{-}$content of the snowpack was on the order of $2700 \mathrm{ng} \mathrm{cm}^{-2}$. In comparison the atmospheric boundary layer column showed a $\mathrm{NO}_{3}^{-}$content of only $8 \mathrm{ng} \mathrm{cm}^{-2}$. The limited exchange, however, between the snow and the atmosphere was attributed to low mobility of $\mathrm{NO}_{3}^{-}$in the observed snow.

Contrary to other Arctic sites (i.e. Alert, Nunavut or Summit, Greenland) deposition of sea salt and crustal aerosols in this marine environment made the surface snow alkaline; snow $\mathrm{NO}_{3}^{-}$was associated with heavier cations and was not readily available for physical exchange or photochemical reactions.

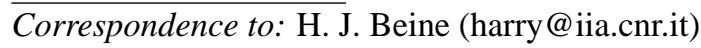

\section{Introduction}

Recent findings of $\mathrm{NO}_{\mathrm{x}}$ and $\mathrm{HONO}$ production in snow interstitial air show that photochemical production of $\mathrm{NO}_{\mathrm{x}}$ in or above snow surfaces is sufficient to alter the composition of the overlying atmosphere (Honrath et al., 1999; Ridley et al., 2000). The current understanding of this process points towards the absorption of some $\mathrm{NO}_{\mathrm{y}}$ species by snow surfaces, the presence and subsequent reduction of $\mathrm{NO}_{3}^{-}$in a surface phase followed by photochemical release of $\mathrm{NO}, \mathrm{NO}_{2}$, and HONO (Honrath et al., 2000; Dubowski et al., 2001). The release of $\mathrm{NO}_{\mathrm{x}}$ and $\mathrm{HONO}$ was quantified during springtime of 2000 at Alert (Canada, $82^{\circ} 27^{\prime} \mathrm{N}, 62^{\circ} 32^{\prime} \mathrm{W}$ ) to be on the order of $40 \mathrm{nmol} \mathrm{m}^{-2} \mathrm{~h}^{-1}$ each (Beine et al., 2002a, Zhou et al., 2001). While the release of active $\mathrm{N}$ has been investigated and quantified, little is known about the sources of snow nitrate and other interactions of $\mathrm{NO}_{3}^{-}$with the snow layer and the atmosphere. At Alert 2000 it was found that the predominant source for snow $\mathrm{NO}_{3}^{-}$was wet deposition during snowfall (Ianniello et al., 2002) (in this work the term 'wet deposition' includes all precipitation scavenging). Snow experiments have been performed at Alert, showing that the mobility and thus availability for photochemical reactions of snow $\mathrm{NO}_{3}^{-}$depend on the temperature, type and acidity of snow (Beine et al., 2002b). We measured during the spring of 2001 at Ny-Ålesund, Svalbard during two intensive campaigns surface fluxes of nitrogen and other atmospheric trace species, detailed aerosol physical and chemical characteristics, as well as snow physics and chemistry.

This paper is part of a series of papers describing the results from the European Community research program "The NItrogen Cycle and Effects on the oxidation of atmospheric trace species at high latitudes" (NICE). The aim of this work is to help identify the atmospheric sources of snow- $\mathrm{NO}_{3}^{-}$, and to help understand the mechanism of the exchange reactions between snow and the atmosphere and also within 
Table 1. Measurement of nitrite and nitrate with denuders/filters and IC analysis ${ }^{a}$

\begin{tabular}{|c|c|c|c|c|}
\hline Species & $\begin{array}{l}\text { Field blank }^{b} \\
\text { measured by IC } \\
\text { during the dark } \\
\text { intensive } \\
\left(\text { pmol mol }^{-1}\right)\end{array}$ & $\begin{array}{l}\text { Field blank }{ }^{b} \\
\text { measured by IC } \\
\text { during the light } \\
\text { intensive }{ }^{d} \\
\left(\mathrm{pmol} \mathrm{mol}^{-1}\right)\end{array}$ & Precision $(\%)^{e}$ & $\begin{array}{l}3 \sigma \text { detection limit } \\
\left(\mathrm{pmol} \mathrm{mol}^{-1}\right)\end{array}$ \\
\hline HONO (gas) & 0.18 & 0.34 & 1.5 & 0.55 \\
\hline $\mathrm{NO}_{2}^{-}$(particle) & 0.18 & 0.34 & 1.2 & 0.57 \\
\hline $\mathrm{HNO}_{3}$ (gas) & 0.19 & 0.39 & 2.57 & 0.27 \\
\hline $\mathrm{NO}_{3}^{-}$(particle) & 0.19 & 0.39 & 3.0 & 1.05 \\
\hline
\end{tabular}

$a$ = These values were calculated using the procedures shown in detail by Perrino et al. (2001) and Beine et al. (2001b).

$b=$ The field blank has the highest contribution to the overall blank. The laboratory and glass blanks are up to ca. $75 \%$ and $40 \%$ of the field blanks for $\mathrm{NO}_{2}^{-}$and $\mathrm{NO}_{3}^{-}$, respectively.

$c=24 \mathrm{~h}$ samples

$d=12 \mathrm{~h}$ samples

$e=$ at ca. $10 \mathrm{pmol} \mathrm{mol}^{-1}$

snow. Other aspects of these exchanges include the chemical composition of aerosols, which are discussed by Teinilä et al. (2003), and physical aerosol characteristics are shown by Nyeki et al. (2002); further papers are in preparation.

\section{Experimental}

\subsection{The Fieldsite at Ny-Ålesund}

The fieldsite was chosen ca. $1.5 \mathrm{~km}$ up-fjord of the NyÅlesund International Arctic Research and Monitoring Facility $\left(78^{\circ} 54^{\prime} \mathrm{N}, 11^{\circ} 53^{\prime} \mathrm{E}\right)$ at Svalbard (see Beine et al., 2001a for a map of the location). The sampling location was at sea level, ca. $20 \mathrm{~m}$ distance from the fjord that unseasonably remained open throughout the arctic winter. The local wind field is documented for this specific location through SODAR measurements; during springtime the majority of the local flow arrived from easterly directions (Beine et al., 2001a).

Measurements were made during two intensive campaigns; a 'dark intensive', 21 February - 8 March (DOY 52 -67), when the sun was below the horizon, and a 'light intensive' during $24 \mathrm{~h}$ sunlight from 24 April - 19 May (DOY 114 - 139).

We used a wind-vane and anemometer connected to shut off valves to discontinue sampling when the air flow arrived from a $120^{\circ}$ sector around the town of $\mathrm{Ny}$-Ålesund or under certain low-flow conditions. This shut-off system protected the denuder/filter measurements, as well as the impactor, and some of the physical aerosol measurements.

\subsection{Denuder/Filter measurements}

Measurements of atmospheric nitrogen species were made with the C.N.R. - IIA denuder/filter system (and ion chro- matographic (IC) analysis) at two sampling altitudes above the snow surface: $2 \mathrm{~cm}(\mathrm{~L})$ and $180 \mathrm{~cm}(\mathrm{H}) .12 \mathrm{~h}$ and 24 $\mathrm{h}$ long samples were collected at both heights, and analyses were subsequently carried out usually within $12 \mathrm{~h}$ at the Italian research station "Base Artica CNR Dirigibile Italia" in Ny-Ålesund.

The annular denuder/filter pack sampling method and the analytical procedures were described previously in detail (Possanzini et al., 1983; Allegrini et al., 1987, Beine et al., 2001b). A brief account is given here for sampling of $\mathrm{NO}_{3}^{-}$ and $\mathrm{NO}_{2}^{-}$species; other species such as $\mathrm{HCl}, \mathrm{HBr}, \mathrm{SO}_{4}^{2-}$ etc. were measured simultaneously with this method. Nitrous acid (HONO) and nitric acid $\left(\mathrm{HNO}_{3}\right)$ in the gas phase were sampled with a combination of sodium fluoride $(\mathrm{NaF})$, sodium carbonate $\left(\mathrm{Na}_{2} \mathrm{CO}_{3}\right)$ and alkaline carbon coated denuders (two of each). This denuder line is followed by a cyclone $(2.5 \mu \mathrm{m}$ aerodynamic diameter cut point) and a filter pack for the collection of atmospheric aerosols, such as nitrate $\left(\mathrm{NO}_{3}^{-}\right)$and nitrite $\left(\mathrm{NO}_{2}^{-}\right)$in the coarse and fine fractions, respectively. The filter pack included a $47-\mathrm{mm}$ Teflon filter (Gelman Teflon, 1- $\mu \mathrm{m}$ pore size) for the collection of particles, a Nylon filter (Nylasorb Gelman, $47 \mathrm{~mm}, 1-\mu \mathrm{m}$ pore size) and two $\mathrm{Na}_{2} \mathrm{CO}_{3}$-glycerol impregnated paper filters (Whatman 41) for the collection of evaporated species from the front Teflon filter. The samples were analyzed by ion chromatography (Dionex IC mod. DX120) using Dionex AS12 column for anions and Dionex CS12 column for cations.

For chromatographic analyses, control samples, consisting of $100 \mathrm{ng} / \mathrm{ml}$ calibration solution of anions $\left(\mathrm{Cl}^{-}, \mathrm{Br}^{-}, \mathrm{NO}_{3}^{-}\right.$, $\mathrm{NO}_{2}^{-}, \mathrm{SO}_{4}^{2-}$ ) and cations $\left(\mathrm{Na}^{+}, \mathrm{NH}_{4}^{+}, \mathrm{K}^{+}, \mathrm{Mg}^{2+}, \mathrm{Ca}^{2+}\right)$, were analyzed every seven samples in order to re-calibrate the ion chromatograph. The variation in the concentration of the control samples was generally of the order $0.5-1 \%$. Cal- 
ibration solutions are prepared every week from $1000 \mathrm{mg} / \mathrm{l}$ standard solutions (MERCK).

Field blanks were measured every 3 days, these blank values are shown in Table 1. To optimize blank values and detection limits of the analytical method and the sampling technique, special care was taken in the field and in the laboratory to the quality control/assurance procedures (Perrino et al., 1990; Ianniello et al., 1999). The detection limits (L.O.D.) of the analytical technique (Table 1) are calculated as the analyte signal which is three times the standard deviation $(3 \sigma)$ of a very low concentration measurement. The L.O.D. for denuder and filter measurements of various particulate and gaseous species (Table 1) are evaluated on the basis of the L.O.D. of the analytical method and of the standard deviations of field blanks (see Beine et al., 2001b; Ianniello et al., 2002 for details). The precision is given here as relative standard deviation (RSD). In the case where field blanks were below the analytical detection limit, the detection limits of species were calculated as the $3 \sigma$ variation of IC baseline noise. Data below the $3 \sigma$ detection limits are shown with their numerical value.

\subsection{Snow sampling}

Snow was sampled regularly for ionic analyses and physical measurements during the spring campaign, with an emphasis on surface snow. The snow stratigraphy was very complex in the spring because of frequent snowfalls that deposited small amounts of snow, and of extensive erosion, remobilization, and (more rarely) accumulation by wind. Moreover, surface melting was also observed twice in the spring, which added further heterogeneity to the snowpack. Because of these features, it was often difficult to identify and monitor a given snow layer. To overcome this difficulty, the snowpack was very carefully observed twice a day or more near the atmospheric sampling site. Layer identification was made on the spot, by observing the crystals with a magnifying glass. When in doubt, crystals were sampled and observed with a photomacrographic equipment in a cold room at $-20^{\circ} \mathrm{C}$ at the Japanese research station 'Rabben'. For ionic analyses, triplicate samples were taken using polyethylene gloves, with the usual precautions to avoid sample contamination, and were analyzed within $12 \mathrm{~h}$ using the IC system described above.

\section{$2.4 \quad 3$-D meteorology and derivation of fluxes}

To derive the characteristics of the surface-atmosphere interaction and to determine the turbulent fluxes we used a sonic anemometer (Metek USAT 1). Additionally, profile measurements of air temperature and wind speed were performed, to be able to compute fluxes of chemical species. The instrument was set up ca. $5 \mathrm{~m}$ from the denuder measurements. The anemometric data were stored in a PC after electronic processing (two axis rotations and the computation of $15 \mathrm{~min}$ averages of the main physical quantities and standard deviations along with the momentum and sensible heat flux determination). The derivation of $\mathrm{HNO}_{3}$ fluxes from this mixed sonic and gradient technique (Sozzi et al., 1998) is described in the Appendix.

\section{Results and discussion}

Numerous data have been obtained for NICE, and only some of the most important points will be selected for discussion. A field campaign with related objective was also performed at Alert, Nunavut, during the spring of 2000 in two intensives (dark and light) (Beine et al., 2002a, b; Dominé et al., 2002; Cabanes et al., 2002; Ianniello et al., 2002). Comparisons between the present data set and those reported from the ALERT 2000 campaign must thus be made. This discussion will focus on the atmospheric $\mathrm{HNO}_{3} / \mathrm{NO}_{3}^{-}$partitioning, on sources of $\mathrm{NO}_{3}^{-}$ions to the snow, and on exchanges of reactive nitrogen species between the snow and the atmosphere.

\subsection{Nitrogen species}

Figure 1 shows the measurement results for gaseous $\mathrm{HONO}$ and $\mathrm{HNO}_{3}$ and total particulate $\mathrm{NO}_{2}^{-}$and $\mathrm{NO}_{3}^{-}$as boxand-whisker plots at both inlets for both intensives. The median values for $\mathrm{HONO}, \mathrm{NO}_{2}^{-}$, and $\mathrm{HNO}_{3}$ were below $5 \mathrm{pmol} \mathrm{mol}^{-1}$ during the dark intensive at both inlets, $\mathrm{NO}_{3}^{-}$ showed a median mixing ratio of 21 and $22 \mathrm{pmol} \mathrm{mol}^{-1}$ at the lower and upper inlet, respectively (at typical dark conditions of $1 \mathrm{~atm}$ and $-20^{\circ} \mathrm{C}$ this corresponds to 62 and $65 \mathrm{ng} / \mathrm{m}^{3}$ $\mathrm{NO}_{3}^{-}$, respectively). $\mathrm{HONO}$ and $\mathrm{NO}_{2}^{-}$increased only slightly until the beginning of the light intensive, their mixing ratios were still below $5 \mathrm{pmol} \mathrm{mol}^{-1}$ at either inlet. $\mathrm{NO}_{3}^{-}$increased by about $1 / 3$ to median values of 28 and $30 \mathrm{pmol} \mathrm{mol}^{-1}$. The most pronounced change between the two intensives can be observed in $\mathrm{HNO}_{3}$; the median mixing ratio increased 5-6 fold to 11 and $18 \mathrm{pmol} \mathrm{mol}^{-1}$ at the lower and upper inlet, respectively. As seen in Fig. 1, the scatter of each measured species did not vary significantly with either sampling height or time.

The difference in mixing ratios $\Delta$ between the two sampling heights $(\Delta=L-H)$ was statistically significant only for $\mathrm{HNO}_{3}$ (Fig. 2). During the light intensive the median was $-5.5 \mathrm{pmol} \mathrm{mol}^{-1}$, which implies deposition to the surface.

\subsection{Aerosol composition}

Numerous data on aerosol composition have already been reported by Teinilä et al. (2003), and we will focus here on aspects relevant to nitrate chemistry. It is important to determine the composition of $\mathrm{NO}_{3}^{-}$bearing particles to assess $\mathrm{NO}_{3}^{-}$reactivity. The data obtained by Teinilä et al. (2003) using a small deposit area impactor (SDI) with 12 collecting 

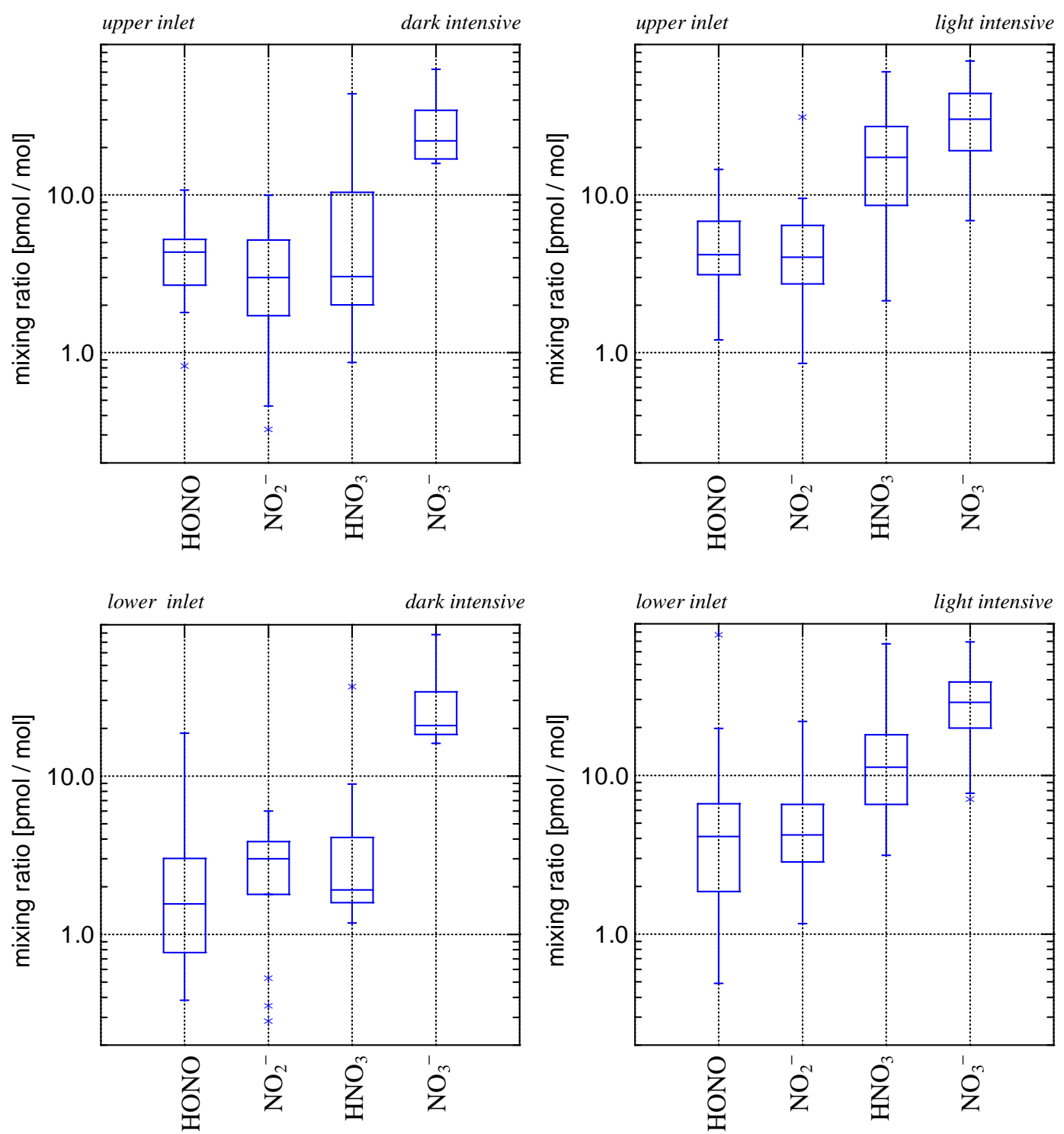

Fig. 1. Box-and-whisker plots of the nitrogen measurements at the lower and upper inlet (lower and upper row, respectively) during the dark and light intensive (left and right column, respectively). In the box the middle line shows the median, the box includes $50 \%$ of the distribution, and the whiskers extend to $95 \%$ of the distribution. Values between the inner and outer fences are plotted with asterisks. Values outside the outer fence are plotted with circles (Systat 9, 1999).

stages indicate that $\mathrm{NO}_{3}^{-}$is mostly found on coarse particles. For particles with an aerodynamic diameter $>1.7 \mu \mathrm{m}$, we found a good correlation between $\mathrm{NO}_{3}^{-}$and $\mathrm{Ca}^{2+}\left(R^{2}>\right.$ 0.7) indicating that $\mathrm{NO}_{3}^{-}$is mostly associated with $\mathrm{Ca}^{2+}$, probably because of the facile reaction between $\mathrm{HNO}_{3}$ and $\mathrm{CaCO}_{3}$ :

$$
\mathrm{HNO}_{3}+\mathrm{CaCO}_{3} \rightarrow \mathrm{Ca}\left(\mathrm{NO}_{3}\right)_{2}+\mathrm{CO}_{2}+\mathrm{H}_{2} \mathrm{O}
$$

that has often been suggested from aerosol measurements (e.g. Prospero et al., 1981) and confirmed by laboratory measurements (e.g. Hanisch and Crowley, 2001). The remaining part of the $\mathrm{NO}_{3}^{-}$is found on particles between 0.8 and
$1.7 \mu \mathrm{m}$, which are probably the smallest sea-salt particles. The $\mathrm{Cl}^{-} / \mathrm{Na}^{+}$ratio of those particles is much less than the marine ratio of 1.8. This could be due to a significant $\mathrm{Na}^{+}$ contribution from crustal dust, however, the $\mathrm{Ca}^{2+}$ data of our size-segregated aerosol measurements (Teinilä et al., 2003) indicate that there is probably not sufficient crustal contribution in this size range to explain the depletion, which then is mostly caused by reactions with $\mathrm{SO}_{4}^{2-}$ and $\mathrm{NO}_{3}^{-}$:

$\mathrm{HNO}_{3}+\mathrm{NaCl} \rightarrow \mathrm{NaNO}_{3}+\mathrm{HCl}$

$\mathrm{H}_{2} \mathrm{SO}_{4}+\mathrm{NaCl} \rightarrow \mathrm{NaHSO}_{4}+\mathrm{HCl}$ 


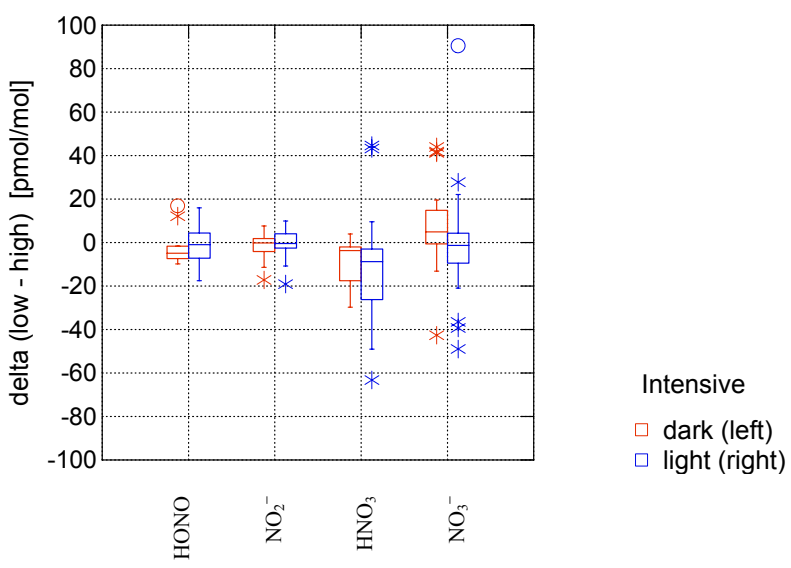

Fig. 2. $\Delta$ (low - high) of nitrogen species during the two intensives. Only $\Delta_{\mathrm{HNO}_{3}}$ was statistically significantly different from zero. During the dark intensive the mean $\Delta_{\mathrm{HNO}_{3}}$ was $-2.90 \mathrm{pmol} \mathrm{mol}^{-1}$ (95\% confidence interval from -5.56 to $-0.24, p=0.0356)$, during the light intensive $\Delta_{\mathrm{HNO}_{3}}$ was $-5.49 \mathrm{pmol} \mathrm{mol}^{-1}$ (95\% confidence interval from -9.39 to $-1.59, p=0.0072$ ). Box-andwhisker plot as in Fig. 1.

A correlation between $\mathrm{Na}^{+}$and $\mathrm{NO}_{3}^{-}$that would confirm the presence of $\mathrm{NO}_{3}^{-}$on those small sea salt particles is difficult to evidence, however, because of the preponderance of $\mathrm{SO}_{4}^{2-}$ in the fractionation process. The involvement of $\mathrm{NO}_{3}^{-}$ in the fractionation process is evidenced by its presence in the coarse mode, with a peak around $2 \mu \mathrm{m}$.

The data obtained using the denuder system were used to calculate the ionic balance of the particles. Particles with aerodynamic diameters below and above $2.5 \mu \mathrm{m}$ were studied separately. The ionic balance of particles, $\left(\mathrm{Cl}^{-}+\mathrm{NO}_{2}^{-}+\right.$ $\left.\mathrm{Br}^{-}+\mathrm{NO}_{3}^{-}+2 \mathrm{SO}_{4}^{2-}\right)-\left(\mathrm{Na}^{+}+\mathrm{NH}_{4}^{+}+\mathrm{K}^{+}+2 \mathrm{Mg}^{2+}+2 \mathrm{Ca}^{2+}\right)$, in units of neq $\mathrm{m}^{-3}$, are shown in Fig. 3. A similar ion balance ((Methanesulfonate (MSA)+ $\mathrm{Cl}^{-}+\mathrm{NO}_{3}^{-}+2 \mathrm{SO}_{4}^{2-}$ $\left.+2 \mathrm{Oxalate})-\left(\mathrm{Na}^{+}+\mathrm{NH}_{4}^{+}+\mathrm{K}^{+}+2 \mathrm{Mg}^{2+}+2 \mathrm{Ca}^{2+}\right)\right)$. from the SDI impactor measurements (Teinilä et al., 2003) showed that acidic particles were found almost exclusively in the size range from ca. 0.15 to $1.06 \mu \mathrm{m}$ in a timeseries as shown in Fig. 3. Teinilä et al. (2003) showed that there is about the same mass of small (acidic) and large (alkaline) particles. Larger particles are more efficiently filtered by snow; thus snow will retain the large alkaline particles, and become alkaline.

To sum up these aerosol chemistry data, it is reasonable to say that most of the particulate $\mathrm{NO}_{3}^{-}$was probably in the form of $\mathrm{Ca}\left(\mathrm{NO}_{3}\right)_{2}$ on crustal aerosols, whose ionic balance suggest that they were not acidic. The remaining part of the $\mathrm{NO}_{3}^{-}$may have been located on sea salt aerosols, in the form of $\mathrm{NaNO}_{3}$, but this remains speculative as reaction (3) conceals a good correlation between $\mathrm{Na}^{+}$and $\mathrm{NO}_{3}^{-}$.

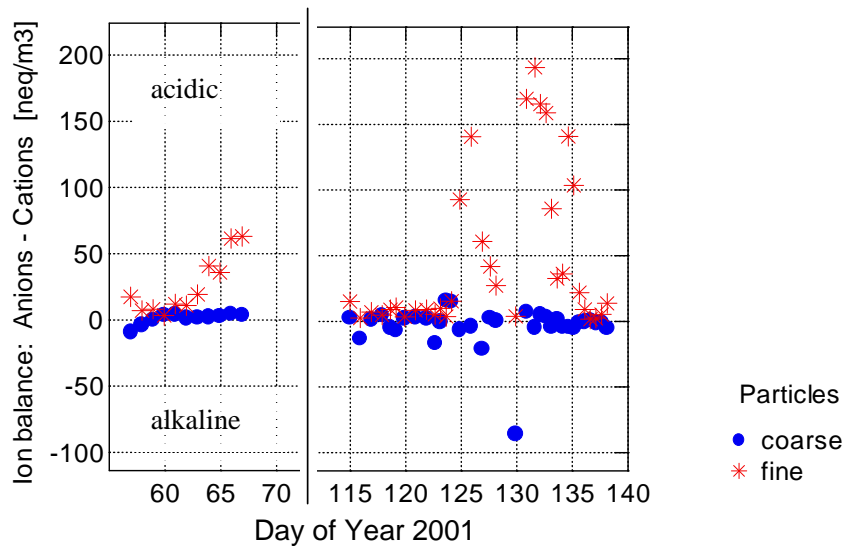

Fig. 3. Ion balance for the high line during both intensives at $\mathrm{Ny}$ Ålesund: $\left(\mathrm{Cl}^{-}+\mathrm{NO}_{2}^{-}+\mathrm{Br}^{-}+\mathrm{NO}_{3}^{-}+2 \mathrm{SO}_{4}^{2-}\right)-\left(\mathrm{Na}^{+}+\mathrm{NH}_{4}^{+}\right.$ $\left.+\mathrm{K}^{+}+2 \mathrm{Mg}^{2+}+2 \mathrm{Ca}^{2+}\right)\left[\right.$ neq $\left.{ }^{-3}\right]$ for coarse $(>2.5 \mu \mathrm{m}$ aerodynamic diameter) (blue circles) and fine $(<2.5 \mu \mathrm{m})$ particles (red stars).

\subsection{Atmospheric $\mathrm{HNO}_{3} / \mathrm{NO}_{3}^{-}$partitioning}

During NICE, $\mathrm{NO}_{3}^{-}$increased by about one third between winter and spring, while $\mathrm{HNO}_{3}$ increased 5-6 fold to 11 and $18 \mathrm{pmol} \mathrm{mol}^{-1}$ at the lower and upper inlet, respectively. As seen in Fig. 1, the scatter of each measured species did not vary significantly with either sampling location or time. At Alert, the winter to spring increase was much greater for $\mathrm{NO}_{3}^{-}: 24.6$ to $48.1 \mathrm{pmol} \mathrm{mol}^{-1}$, and much smaller for $\mathrm{HNO}_{3}$ : 2.0 to $8.5 \mathrm{pmol} \mathrm{mol}^{-1}$ (Ianniello et al., 2002). While the light conditions at Alert were similar to those during our intensives at Ny-Ålesund, Alert was much colder, and drier, and there was much less air movement. The composition of aerosols and the ratios of $\mathrm{HNO}_{3} / \mathrm{NO}_{3}^{-}$are a function of temperature, aerosol composition and acidity, as well as the kinetics of production/destruction/deposition of both $\mathrm{HNO}_{3}$ and $\mathrm{NO}_{3}^{-}$. Since this system is very complex, we must limit ourselves to qualitative considerations.

At $\mathrm{Ny}$-Ålesund higher temperatures favor volatilization of $\mathrm{HNO}_{3}$ from the aerosol and the snow; additionally, higher $\mathrm{NO}_{\mathrm{x}}$ mixing ratios (Beine et al., 1997; 2002a) will lead to increased $\mathrm{HNO}_{3}$ formation. Due to the stronger winds, it can be suggested that dry deposition of $\mathrm{NO}_{3}^{-}$may be favored by the filtering of particles by snow. These elements will favor a higher $\mathrm{HNO}_{3} / \mathrm{NO}_{3}^{-}$ratio at $\mathrm{Ny}$-Ålesund than at Alert. This may be counterbalanced by the alkaline or neutral character of the coarse aerosol (the fine particles are acidic) at $\mathrm{Ny}$ Ålesund, which will favor $\mathrm{HNO}_{3}$ uptake and its conversion to $\mathrm{NO}_{3}^{-}$. An ion balance at Alert suggested that the aerosol during springtime was acidic, and would thus favor the free acid. However, since the ratio $\mathrm{HNO}_{3} / \mathrm{NO}_{3}^{-}$is greater at $\mathrm{Ny}$ Allesund, we must conclude that the greater aerosol alkalinity is insufficient to compensate for the warmer temperatures 

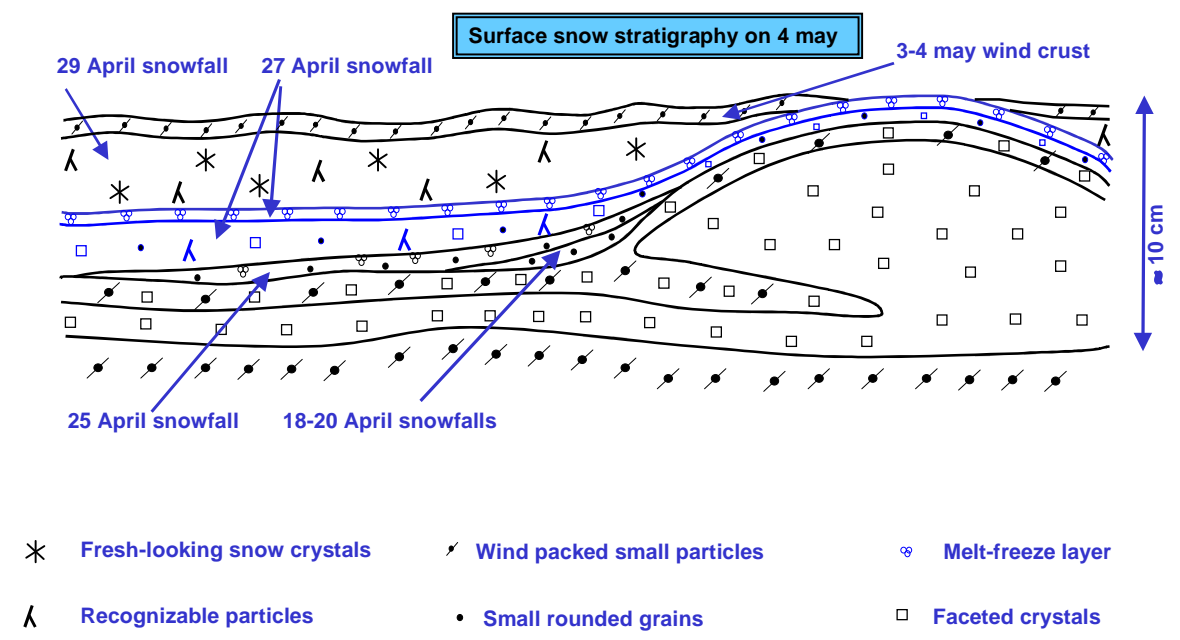

$\propto$ Melt-freeze layer
$\square \quad$ Faceted crystals

Fig. 4. Surface stratigraphy of the snowpack near the Amundsen mast. The total thickness of the snowpack is about $40 \mathrm{~cm}$.

and higher $\mathrm{HNO}_{3}$ production from $\mathrm{NO}_{\mathrm{x}}$, and that these latter processes are probably predominant in the determination of $\mathrm{HNO}_{3} / \mathrm{NO}_{3}^{-}$.

\subsection{Snow stratigraphy and $\mathrm{NO}_{3}^{-}$concentration in snow}

The snow stratigraphy was very complex. Most of the stratigraphic observations were made near the Amundsen mast (ca. $100 \mathrm{~m}$ to the south inland from the atmospheric sampling location). The accumulation at these coastal sites is less than on locations further inland because of strong wing erosion. Nine snowfall events were observed between 18 April and 9 May. Many of them were blown away by wind and did not contribute to accumulation. The 25 April (DOY 115) and 27 April (DOY 117) snowfalls were stabilized by the formation of a thin melt-freeze crusts and were monitored in detail. The 29 April (DOY 119) snowfall was over $5 \mathrm{~cm}$ thick and was not eroded until 8 May, and then only partially so, so it could also be studied over an extended period. The surface snow stratigraphy on 4 May (DOY 124) is shown in Fig. 4, to illustrate its complexity.

In general, the snow composition was found to be very variable within a given layer, both vertically and horizontally. This is not due to contamination problems, as sampling in unperturbed areas yielded little variation $(<5 \%$ between triplicate samples). (Moreover, the sampling and analysis procedures were similar to those used at Alert, where there was little wind, and where variations amongst triplicates were also $<5 \%$ ). The vertical variation can simply be attributed to varying atmospheric composition during precipitation. The horizontal variation can probably be explained by the action of wind during precipitation. Wind will raise older snow that has a composition different from falling snow. Mixing of falling snow with older snow in different proportions will result in a variable snow composition.
Other factors may also come into play. Many different snow layers with different compositions were outcropping at different places. Exchanges of solutes between recent and older layers, for example by remobilization during metamorphism, will produce lateral variations in composition. These variations added noise to the data, even though we attempted to sample one given snowbank, and progressed within this snowbank with every sampling in an effort to minimize the effects of horizontal variations.

Figure 5 shows the variation of the $\mathrm{NO}_{3}^{-}$concentration in the snow that precipitated on 27 April (DOY 117; Fig. 5a) and 29 April (DOY 119; Fig. 5b). The 27 April layer was covered by the 29 April snowfall and was not exposed again until 8 May (DOY 128), when only parts of it outcropped again. Of the $5 \mathrm{~cm}$-thick 29 April snowfall both the middle and the top layer were sampled. The bottom part was not sampled to avoid contamination of the underlying 27 April layer that was richer in $\mathrm{NO}_{3}^{-}$. The windpacked sublayer that formed on top of the 29 April layer on 4 May (DOY 124) was sampled after its formation. This wind-pack formed by windinduced sintering of surface snow, rather than by wind deposition of snow. We observe no significant trend in $\mathrm{NO}_{3}^{-}$concentrations in these layers, which is consistent with the role of sea-salt in the surface layer to prevent loss of $\mathrm{NO}_{3}^{-}$. The sum of the two 27 April sublayers in Fig. 5a seems to remain constant, which suggests that exchange amongst sublayers may have taken place, without a net emission. The one significant observation is that the formation of the windpacked sub-layer was accompanied by an increase in the $\mathrm{NO}_{3}^{-}$concentration. This can be explained by sublimation induced by air circulation. If $\mathrm{NO}_{3}^{-}$is present in particulate form, it will not be affected by sublimation and its concentration will increase. Alternatively, it can also be suggested that the snow filtered out $\mathrm{NO}_{3}^{-}$containing particles. 

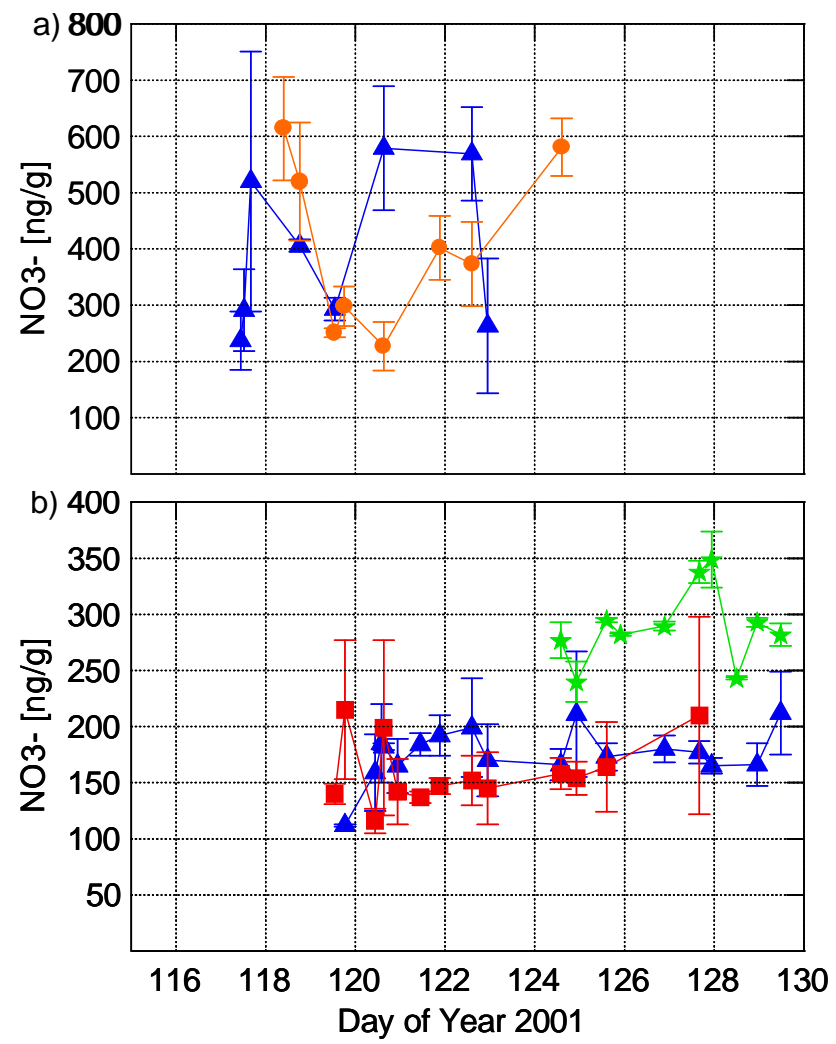

Fig. 5. (a) Time series of the $\mathrm{NO}_{3}^{-}$content of the 27 April 2001 snowfall. The top (blue triangles) and bottom (orange circles) parts of the layer were sampled separately. (b) Time series of the $\mathrm{NO}_{3}^{-}$ content of the 29 April 2001 snowfall. The top (blue triangles) and middle (red squares) layers were sampled separately. The very top of the layer became windpacked on 4 May 2001, and was subsequently sampled separately (green stars). Error bars are standard deviations in triplicate samples.

\subsection{Atmospheric stability and $\mathrm{HNO}_{3}$ fluxes}

Figures $6 \mathrm{a}-\mathrm{c}$ show the overall meteorological conditions during our experiment at $\mathrm{Ny}-\AA ̊$ Alesund. Figure $6 \mathrm{~d}$ shows the friction velocity $u_{*}\left(u_{*}=\tau / \rho\right.$, where $\rho$ is the air density, and $\tau$ the in situ momentum flux), derived from the mixed micrometeorological measurements. No diurnal pattern was significant for $u_{*}$ over the duration of the light intensive, except that the variability was slightly increased in the morning hours. While the majority of the $u_{*}$ values fall below $0.15 \mathrm{~ms}^{-1}$, values up to $0.3 \mathrm{~ms}^{-1}$ were observed corresponding to days with higher windspeeds.

Using both the measured $\Delta_{\mathrm{HNO}_{3}}$ and the measured eddy diffusivity for the same time period, the atmospheric surface fluxes for $\mathrm{HNO}_{3}$ were derived (Fig. 7). The average value for the deposition flux was $-8.7 \mathrm{nmol} \mathrm{h}^{-1} \mathrm{~m}^{-2}$ (and was statistically significant, $p=0.0229, t=-2.3908,95 \% \mathrm{CI}=$ \pm 7.46 ). Two extreme values of -60 and $-80 \mathrm{nmol} \mathrm{m}^{-2} \mathrm{~h}^{-1}$ $\mathrm{HNO}_{3}$ deposition were observed during the largest observed

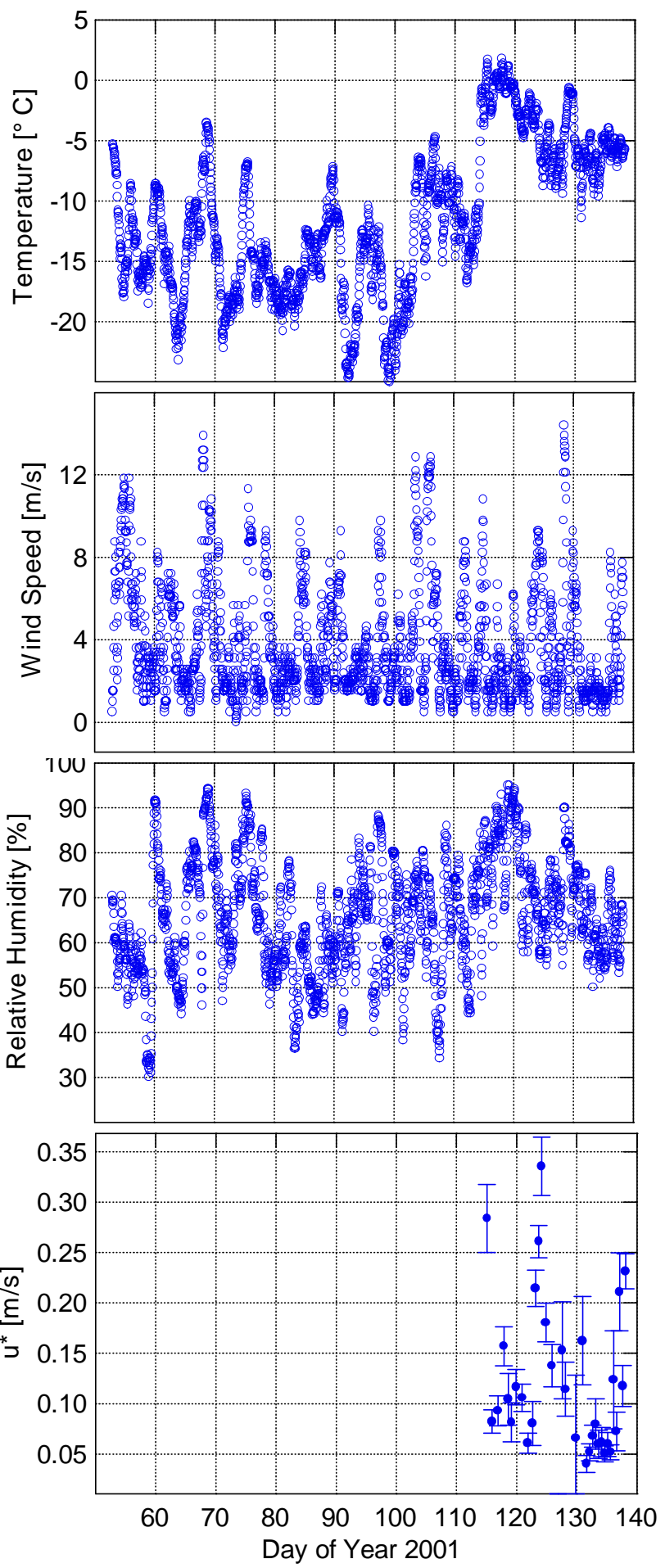

Fig. 6. (a)-(c) Meteorology at $\mathrm{Ny}-\AA ̊$ llesund during spring 2001. (d) Variability of $u_{*}$ during the light intensive. The dots show the mean value during each denuder sampling period, the error bars show the $95 \%$ confidence interval for that time period.

snowfall during our campaign (DOY 119). The winds were calm $\left(<3 \mathrm{~ms}^{-1}\right)$, temperatures and relative humidities very 


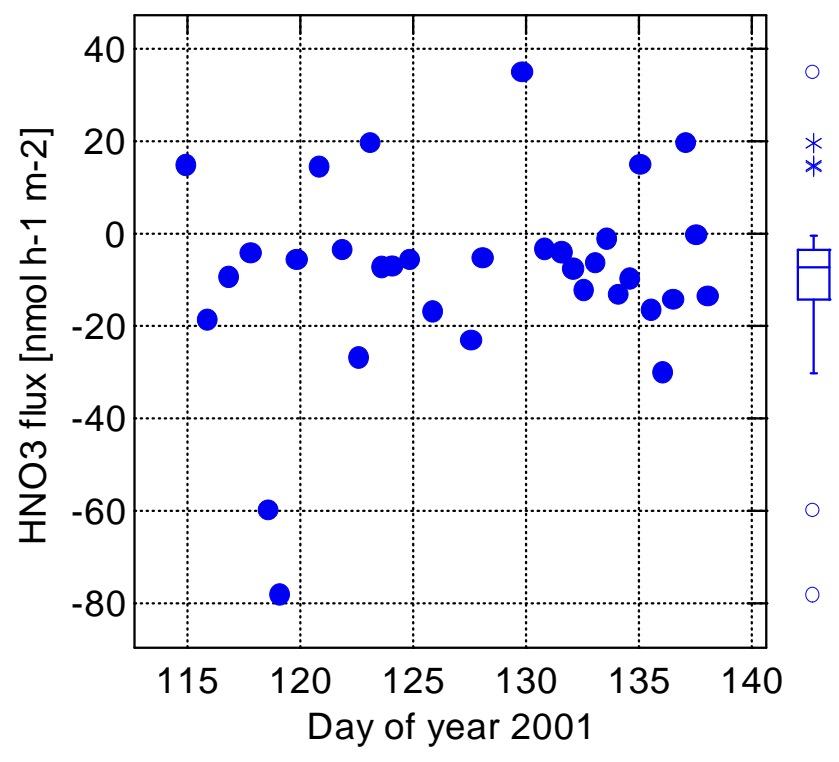

Fig. 7. $\mathrm{HNO}_{3}$ flux above the snow surface derived from denuder measurements at $2 \mathrm{~cm}$ and $180 \mathrm{~cm}$ above the snow surface. The box-and-whisker plot to the right shows the entire distribution.

high. The observed $\mathrm{HNO}_{3}$ concentrations on this day, however, were the highest observed. The measurement at the upper line was $116 \mathrm{pmol} / \mathrm{mol}$. This suggests that the airmass brought $\mathrm{HNO}_{3}$ with the snow, and $\mathrm{HNO}_{3}$ was scavenged by that snowfall and deposited to the surface.

\subsection{Sources of $\mathrm{NO}_{3}^{-}$ions to the snow}

Surface snow at $\mathrm{Ny}$-Ålesund showed $\mathrm{NO}_{3}^{-}$mixing ratios of $65-520 \mathrm{ng} / \mathrm{g}$. Three distinct sources of nitrate contribute to this signal; (1) The major fraction of $\mathrm{NO}_{3}^{-}$is contained in precipitating snow; (2) $\mathrm{HNO}_{3}$ is scavenged during precipitation (though we cannot differentiate between these two sources); and (3) $\mathrm{HNO}_{3} / \mathrm{NO}_{3}^{-}$is dry deposited independently of precipitation. The first two mechanisms are illustrated by the 29 April snowfall event, which was mentioned above: The nitrate content in the falling snow corresponds to the surface snow layers later sampled; We sampled on 29 April surface snow while snow was still falling, and hence saw a good approximation of falling snow. The $\mathrm{NO}_{3}^{-}$content of this surface snow did not change afterwards. Neither $\mathrm{HNO}_{3}$ nor dry particle $\mathrm{NO}_{3}^{-}$deposition were large at $\mathrm{Ny}$ Ålesund, so that the main $\mathrm{NO}_{3}^{-}$source for snow seems to be wet deposition in falling snow. A similar conclusion was reached for Alert 2000 (Ianniello et al., 2002).

The largest observed source of $\mathrm{HNO}_{3}$ was deposition during the major snowfall on DOY 119. During that snowfall $5 \mathrm{~cm}$ snow of density $0.12 \mathrm{gcm}^{-3}$ fell with a $\mathrm{NO}_{3}^{-}$content of $200 \mathrm{ng} / \mathrm{g}$. Assuming that the high $\mathrm{HNO}_{3}$ deposition of -60 to $-80 \mathrm{nmol} \mathrm{m}^{-2} \mathrm{~h}^{-1}$ (see above) lasted for $24 \mathrm{~h}$, the contribution of gaseous $\mathrm{HNO}_{3}$ to the $\mathrm{NO}_{3}^{-}$content in the fresh snow is only ca. $10 \%$.

Dry deposition of $\mathrm{HNO}_{3}$, though small, was statistically significant at $\mathrm{Ny}$-Ålesund on most days (Fig. 7), while this was not the case at Alert. This difference between both sites may be related to the sea salt content of the snow. At NyÅlesund, the median $\mathrm{Cl}^{-}$was about $1500 \mathrm{ng} / \mathrm{g}$. At Alert, it was about $250 \mathrm{ng} / \mathrm{g}$ before a storm event on 25-29 April 2000. That storm brought in marine air, increasing $\mathrm{Cl}^{-}$to about $1500 \mathrm{ng} / \mathrm{g}$. It can then be hypothesized that the reaction (2) led to $\mathrm{HNO}_{3}$ deposition to the snow (Fenter et al., 1994). The rate obviously depends on the concentration of $\mathrm{NaCl}$, and thus would be much more efficient at $\mathrm{Ny}$-Ålesund, relative to pre-storm Alert. Indeed, for the 3 days prior to the storm, the snow at Alert was a small source of $\mathrm{HNO}_{3}$; during the storm it was a sink of about equal strength (up to $30 \mathrm{nmol} \mathrm{m}^{-2} \mathrm{~h}^{-1}$, comparable to the observed $\mathrm{NO}_{\mathrm{x}}$ and HONO emissions; Beine et al., 2002a). After the storm no $\mathrm{HNO}_{3}$ fluxes were detected anymore.

Fresh snow usually contains little sea salt, and is slightly acidic (the snow ion-balance shows an acidity of about $4 \mu \mathrm{eq} / \mathrm{L}$ ). Wind deposition of sea salt, which is alkaline (Stumm and Morgan, 1970) turns the snow alkaline (the snow ion-balance shows alkalinity of 10 to $40 \mu \mathrm{eq} / \mathrm{L}$ ). Therefore surface snow that has been exposed to sea salt is a good sink for $\mathrm{HNO}_{3}$. Deeper snow layers may remain acidic and release $\mathrm{HNO}_{3}$, which immediately gets trapped in the alkaline surface layer.

Under the crude assumption that our observed mean $\mathrm{HNO}_{3}$ fluxes hold true for an entire winter season (September to May) we can assess the influence of this atmospheric deposition to the snow surface. The accumulation of snow $\mathrm{NO}_{3}^{-}$from atmospheric $\mathrm{HNO}_{3}$ was on the order of $8.7 \mathrm{nmol} \mathrm{hr}^{-1} \mathrm{~m}^{-2}$, or $1.2 \mathrm{ng} \mathrm{cm}^{-2} \mathrm{day}^{-1}$. If this affected the surface layer (top $5 \mathrm{~cm}$ ) of the snow, of mean density of $0.2 \mathrm{~g} \mathrm{~cm}^{-3}$, the increase was $1.2 \mathrm{ppbw}(\mathrm{ng} / \mathrm{g}) \mathrm{day}^{-1}$. This change is virtually impossible to detect in the snow.

Dry deposition of $\mathrm{NO}_{3}^{-}$particles were not observed in statistically significant quantity at $\mathrm{Ny}$-Ålesund. However, we see evidence that the observed surface snow layers gain $\mathrm{Na}^{+}$ and $\mathrm{Ca}^{2+}$ over time; though much more $\mathrm{Na}^{+}$than $\mathrm{Ca}^{2+}$. This difference in the efficiency of dry particle capture may depend on the particle nature. A $\mathrm{NaCl}$ particle is likely to dissolve upon contact with the snow surface, and will thus easily stick. Crustal $\mathrm{CaCO}_{3}$, on the other hand, does dissolve much slower, and is likely to bounce off. Thus dry deposition during increased wind deposits preferably soluble ions. Since $\mathrm{NO}_{3}^{-}$is connected with crustal particles, the observed gradients (Fig. 2) were too small to be observed with our sampling methods. Additionally, as yet undocumented chemical transformations of $\mathrm{NO}_{\mathrm{y}}$ reservoir species such as peroxyacetyl nitrate (PAN) or alkyl nitrates to $\mathrm{NO}_{3}^{-}$in the snow phase (Ford et al., 2002) may be possible. Beine and Krognes (2000) showed an anticorrelation of PAN mixing ratios with the relative atmospheric humidity at Ny-Ålesund, but no further ev- 
idence is available that PAN, or alkyl nitrates, lead to a nitrate signal in snow, either directly or indirectly.

In conclusion; most of the nitrate signal in snow is determined at deposition, and little modification takes place afterwards. Dry deposition of $\mathrm{HNO}_{3}$ occurs, and is enhanced by the presence of $\mathrm{NaCl}$.

3.7 Exchanges of reactive nitrogen species between the snow and the atmosphere

Significantly, no emissions of HONO were observed during the spring of 2001 next to the unseasonably unfrozen fjord at Ny-Ålesund. HONO emissions were observed at both Alert and Summit (Zhou et al., 2001; Honrath et al., 2002) and were attributed to the photolysis of the nitrate ion contained in snow, and subsequent reaction of the primary photolysis products with water in the acidic snow environment. $\mathrm{NO}_{\mathrm{x}}$ at Alert was also produced by nitrate photolysis in the snow in a ratio $\mathrm{NO}_{\mathrm{x}}$ : HONO of 1:1 (Beine et al., 2002a), however, it is conceivable that in the alkaline snow environment of $\mathrm{Ny}$ Ålesund HONO formation from primary photolysis products was not occurring. No measurements of $\mathrm{NO}_{\mathrm{x}}$ were made during the spring of 2001 at $\mathrm{Ny}$-Ålesund. If, however, the release mechanisms and ratios are similar at $\mathrm{Ny}$-Ålesund to those at Alert, we may speculate that $\mathrm{NO}_{\mathrm{x}}$ was not emitted from the snowpack at $\mathrm{Ny}$-Ålesund.

Further, the surface snow content of $\mathrm{NO}_{3}^{-}$was invariable with time. These observations are in contrast to our findings at Alert during the spring of 2000, where up to $45 \%$ of the $\mathrm{NO}_{3}^{-}$decrease in a surface snow layer (of $30 \mathrm{~mm}$ thickness of ca. $1.8 \mu \mathrm{mol} \mathrm{m}^{-2} /$ day over a period of 2 weeks of no new snow fall) could be attributed to photolysis (Beine et al., 2002a). Thus, even though snow at Alert (Beine et al., 2002b; Dominé et al., in preparation), Summit (Honrath et al., 2002), and $\mathrm{Ny}$-Ålesund showed similar nitrate contents, the resulting emissions appeared very different at $\mathrm{Ny}-\AA ̊ \AA l e s u n d$. Above we have discussed how snow composition, and the effect of sea-salt may affect $\mathrm{HNO}_{3}$ uptake. In the following we will investigate how snow composition may affect nitrate reactivity.

Snowpack $\mathrm{NO}_{3}^{-}$had the potential to affect atmospheric composition. The $\mathrm{NO}_{3}^{-}$concentration in the snow at $\mathrm{Ny}-$ Ålesund was 65 to $520 \mathrm{ppbw}$, with a total $\mathrm{NO}_{3}^{-}$content of the snowpack on the order of $2700 \mathrm{ng} / \mathrm{cm}^{2}$ (or $435 \mu \mathrm{mol} \mathrm{m}{ }^{-2}$ ) near the Amundsen mast. This value was up to 5 times higher in areas that were not wind-swept, and where snow accumulation reached up to $2 \mathrm{~m}$. This is 10 times more than the value from atmospheric $\mathrm{HNO}_{3}$ deposition alone. Atmospheric $\mathrm{NO}_{3}^{-}$concentrations of ca. $200 \mathrm{ng} / \mathrm{m}^{3}$ (ca. $70 \mathrm{pmol} \mathrm{mol}{ }^{-1}$; as $\mathrm{HNO}_{3}$ and particulate $\mathrm{NO}_{3}^{-}$) add up to a column boundary layer $(300 \mathrm{~m})$ content of only $8 \mathrm{ng} / \mathrm{cm}^{2}$. Thus even a release of $\mathrm{NO}_{3}^{-}$by the snowpack that would result in undetectable changes in snow composition, had the potential to considerably increase boundary layer $\mathrm{NO}_{3}^{-}, \mathrm{HONO}$ or $\mathrm{NO}_{\mathrm{x}}$ concentrations.

Although the details of the photolysis mechanism of $\mathrm{NO}_{3}^{-}$ photolysis in natural snow are not clear, it has been suggested that photolysis will be facilitated if $\mathrm{NO}_{3}^{-}$is located on the surface of snow crystals (Dubowski et al., 2001). If $\mathrm{NO}_{3}^{-}$ is dissolved in the crystalline lattice of ice, or trapped inside aerosol particles, recombination of products due to the cage effect may considerably reduce emissions. $\mathrm{HNO}_{3}$ readily adsorbs onto snow crystals (Abbatt, 1997; Zondlo et al., 1997) while its solubility into the ice crystalline lattice is low (Thibert and Dominé, 1998). Thus, if $\mathrm{NO}_{3}^{-}$in snow is associated to $\mathrm{H}^{+}$, it can be suggested that it will be located on the surface of snow crystals and readily available for photolytic activation and physical exchange. However, while at Alert snow nitrate decreased with time along with the specific surface area (SSA) of snow (Beine et al., 2002b; Cabanes et al., 2002), we observed no decrease in snow nitrate for the 29 April snowfall at $\mathrm{Ny}$-Ålesund despite a factor of 2 decrease in snow SSA in just 3 days. This leads to the suggestion that $\mathrm{NO}_{3}^{-}$in snow was not located on the surface of snow crystals, and that it was not associated with $\mathrm{H}^{+}$. This is confirmed by the ionic measurements that lead to the conclusion that the surface snow was most of the time alkaline, because of sea salt and crustal aerosol deposition. The chemical form of snow $\mathrm{NO}_{3}^{-}$may be constrained further; in particular it is essential to determine whether it is in the form of $\mathrm{NH}_{4} \mathrm{NO}_{3}$, which is fairly unstable and can thus lead to facile physical exchange (Mozurkewich, 1993), or associated with $\mathrm{Ca}^{2+}$, $\mathrm{Mg}^{2+}$, or $\mathrm{Na}^{+}$, leading to stable forms of $\mathrm{NO}_{3}^{-}$.

The median snow $\mathrm{NH}_{4}^{+}$concentrations from different layers of various snowfalls at $\mathrm{Ny}$-Ålesund was only $31 \mathrm{ng} / \mathrm{g}$; this amounted to $2.5 \%$ of all available equivalent cations. Additionally, Teinilä et al. (2003) showed that no correlation existed between $\mathrm{NH}_{4}^{+}$and $\mathrm{NO}_{3}^{-}$in the atmospheric aerosol, but that $\mathrm{NH}_{4}^{+}$was associated with $\mathrm{SO}_{4}^{2-}$, and $\mathrm{NO}_{3}^{-}$with $\mathrm{Ca}^{2+}$. Hence the majority of $\mathrm{NO}_{3}^{-}$in aerosols was present as $\mathrm{Ca}\left(\mathrm{NO}_{3}\right)_{2}$, which is fairly stable. This preferential association of $\mathrm{NO}_{3}^{-}$with $\mathrm{Ca}^{2+}$ is frequently observed in marine air when crustal aerosols are present (e.g. Zhuang et al., 1999). In snow, determining the chemical form of $\mathrm{NO}_{3}^{-}$is more difficult, because we lose the size-dependent composition. However, the chemistry of the 29 April snow layer illustrates interesting changes. The initial composition of that snow was calcium-poor (10 to $20 \mathrm{ppbw}$ ), and it was acidic. The composition of the top sublayer changed, and $\mathrm{Ca}^{2+}$ reached about 50 ppbw within one day, presumably because of the dry deposition of crustal aerosol, while the snow became alkaline (by about $5 \mu \mathrm{eq} / \mathrm{L}$ ). With the formation of the wind crust, $\mathrm{Ca}^{2+}$ increased to 300 ppbw, while the alkalinity increased to $10-40 \mu \mathrm{eq} / \mathrm{L}$. $\mathrm{Na}^{+}$was the most abundant cation, around 2000 ppbw, while there were 300 ppbw of $\mathrm{Mg}^{2+}$ and $\mathrm{Ca}^{2+}$. Since we do not know whether the particles deposited onto the snow retained their individu- 
ality or whether they became dissolved in snow, it is difficult to determine the form of $\mathrm{NO}_{3}^{-}$in snow. However, considering that the snow is alkaline, and that the major cations are $\mathrm{Na}^{+}, \mathrm{Ca}^{2+}$ and $\mathrm{Mg}^{2+}$, the most reasonable hypothesis is that in snow, $\mathrm{NO}_{3}^{-}$is associated with one of these ions and is therefore fairly inert with regard to physical exchanges. It is possible that aerosol $\mathrm{Ca}\left(\mathrm{NO}_{3}\right)_{2}$ remains in the particle form; crustal aerosols have been observed inside ice crystals in ice cores (Fuji et al., 1999). With snow metamorphism, particles can then become imbedded inside ice crystals, thus becoming isolated from the atmosphere and therefore unreactive.

Alternatively, ionic species may interact with ice to form ionic mixtures that could even be liquid, and that would spread on the ice crystal surfaces (Koop et al., 2000). In that case, $\mathrm{NO}_{3}^{-}$may be potentially reactive. However, release of surface $\mathrm{NO}_{3}^{-}$as $\mathrm{HNO}_{3}$ would require an acidic medium, which appears incompatible with the increase in snow alkalinity after snowfall. Moreover, such $\mathrm{HNO}_{3}$ emissions were not observed, and the arguments just developed, together with the observations, lead to the conclusion that $\mathrm{NO}_{3}^{-}$in snow at Ny-Ålesund is (i) not reactive towards physical exchange with the atmosphere, because it is associated with counter cations such as $\mathrm{Na}^{+}$or $\mathrm{Ca}^{2+}$. (ii) not reactive towards photolysis, probably because it is not located on the surface of snow crystals; it may be either trapped inside particles or, less likely, trapped inside the ice crystalline lattice. The potential for exchanges may thus not be as high as suggested by the partitioning of nitrate between the atmosphere and the snow.

\section{Conclusions}

At Ny-Ålesund during the spring of 2001 at a coastal site close to the unseasonably unfrozen fjord only deposition fluxes of $\mathrm{HNO}_{3}$ were detected. Other measured nitrogen species showed no significant fluxes which may be in part due to the measurement uncertainties and long integration times of the used denuder technique, and atmospheric turbulence and mixing. These $\mathrm{HNO}_{3}$ fluxes may be due to the reaction of $\mathrm{HNO}_{3}$ with sea salt contained in the snow, and especially $\mathrm{NaCl}$, or may be simply uptake of $\mathrm{HNO}_{3}$ by ice, which is alkaline because of the sea salt in our marine environment.

At Alert and Summit, the snow was acidic. $\mathrm{NO}_{3}^{-}$was thus mainly associated with $\mathrm{H}^{+}$. It was probably located on the surface of snow crystals and was available for physical exchanges and for photochemical reactions, that led to $\mathrm{HONO}$ and $\mathrm{NO}_{\mathrm{x}}$ emissions by the snowpack. At $\mathrm{Ny}-$ Ålesund, HONO emission was not observed from alkaline snow. Although fresh snow was often acidic, deposition of sea salt and crustal aerosols in this marine environment made the snow alkaline, and $\mathrm{NO}_{3}^{-}$was then associated with heavier cations. Although it is not clear whether $\mathrm{NO}_{3}^{-}$was actually incorporated in the snow crystals or remained within aerosol particles, we suggest that it was not readily available for physical exchange or photochemical reactions. If such reactions did take place, formation and/or release of products was hindered by cage effects or trapping in solids. To confirm whether alkaline snow does not reactivate nitrates or whether photolysis paths and/or products are different, measurements of $\mathrm{NO}_{\mathrm{x}}$ fluxes are still necessary.

These results lead to the conclusion that understanding $\mathrm{NO}_{3}^{-}$exchanges between the snow and the atmosphere will require more efforts in determining what contributes to the $\mathrm{NO}_{3}^{-}$signal in snow (Dibb et al., 1998). We also need to understand nitrate localization and reactivity in snow, and whether it interacts with $\mathrm{NH}_{4}^{+}$or heavier cations such as $\mathrm{Ca}^{2+}$ and $\mathrm{Na}^{+}$inside particles or dissolved in ice crystals. This also relates to how nitrates are seen in ice cores from the much dustier last glacial periods (Rothlisberger et al., 2000, 2003). It is then clear that understanding the impact of snow $\mathrm{NO}_{3}^{-}$on atmospheric composition will require microphysical investigation of the snow, and in particular how aerosol particles interact with snow. It is crucial to determine whether soluble species remain within aerosol particles as a separate phase, or whether they become dissolved in ice.

Finally, we have shown here that reactivity of species in the snow phase will depend on their chemical state, and on other species, that influence reactivity (e.g. pH). This supports recent suggestions by Dominé and Shepson (2002) that the mechanism and magnitude of emissions of other species, such as HCHO, by snow would depend on its overall composition. A larger number of locations with different atmospheric and snow compositions will have to be studied before the overall impact of snow on atmospheric chemistry can be estimated reliably.

\section{Appendix - Calculation of $\mathrm{HNO}_{3}$ surface fluxes}

Using a mixed sonic and gradient technique (Sozzi and Favaron, 1996), atmospheric stability and surface fluxes were determined.

The first step of an eddy-correlation process is the calculation of the perturbation value of each data point; by way of example, the vertical wind speed component $\boldsymbol{w}$ was considered, which can be written as (Stull, 1988)

$\boldsymbol{w}(t)=\bar{w}+w^{\prime}(t)$,

where $\boldsymbol{w}$ is the measured value, $\bar{w}$ is the mean value and $w^{\prime}$ is the fluctuation value. From a time series of data, the mean and the fluctuation values can be determined for each variable. To calculate heat fluxes, we need to know time series for the temperature, (for the sensible heat flux), and the specific humidity, (for the latent heat flux). Then the respective fluctuations are multiplied with each other, which yields the following time series:

$w^{\prime} T^{\prime}(t), w^{\prime} T^{\prime}(t+\Delta t), w^{\prime} T^{\prime}(t+2 \Delta t)$, 
.... for the sensible heat flux,

$w^{\prime} q^{\prime}(t), w^{\prime} q^{\prime}(t+\Delta t), w^{\prime} q^{\prime}(t+2 \Delta t)$,

.... for the latent heat flux.

Finally, the averages of the series $\overline{w^{\prime} T^{\prime}}$ and $\overline{w^{\prime} q^{\prime}}$ constitute the useful quantities for the computation of the latent and heat fluxes

$H_{0}=\rho C_{p} \overline{w^{\prime} T^{\prime}}$

$L E=\lambda \overline{w^{\prime} q^{\prime}}$

where $\rho$ is the air density, $C_{p}$ is the specific heat of the air at constant pressure and $\lambda$ is the latent heat of sublimation. In the same way also the friction velocity can be determined by the covariance between $w$ and $u$.

$u_{*}=\sqrt{-\overline{u^{\prime} w^{\prime}}} \quad$ (in streamline coordinates)

Because our aim is to compute $\mathrm{HNO}_{3}$ fluxes for the time integrated (12 h) $\mathrm{HNO}_{3}$ samples a combined eddy covariance and gradient technique were applied. Following the MoninObukhov similarity theory, the vertical profile of a generic scalar in the surface layer can be represented by the same universal similarity function of air temperature. First of all it is necessary to define the scale parameter for a generic gas concentration $c_{*}$ :

$c_{*}=-\frac{\overline{w^{\prime} c^{\prime}}}{u_{*}}$

The similarity function for the vertical profile of a generic gas $c$ will be given by the relation:

$c\left(z_{2}\right)-c\left(z_{1}\right)=\frac{c_{*}}{k} \cdot\left\{\ln \frac{z_{2}}{z_{1}}-\Psi_{H}\left(\frac{z_{2}}{L}\right)+\Psi_{H}\left(\frac{z_{1}}{L}\right)\right\}(\mathrm{A} 5 \mathrm{a})$

where the universal similarity function is:

$\Psi_{H}= \begin{cases}2 \ln \left[\frac{1+\sqrt{1-16 z / L}}{2}\right] & \text { if } \mathrm{z} / \mathrm{L}<0 \\ -17 \cdot[1-\exp (-0.29 z / L)] & \text { if } \mathrm{Z} / \mathrm{L}>0\end{cases}$

and $z / L$ is the stability parameter derived from sonic anemometer measurements. If we equate $\Delta Q=c\left(z_{1}\right)-$ $c\left(z_{2}\right)$, the relation between $\Delta Q$ and the $\mathrm{HNO}_{3}$ vertical flux will be:

$\overline{w^{\prime} c^{\prime}}=-u_{*} c_{*}=+\Delta Q \frac{k u_{*}}{\ln \frac{z_{2}}{z_{1}}-\Psi_{H}\left(\frac{z_{2}}{L}\right)+\Psi_{H}\left(\frac{z_{1}}{L}\right)}$

Now we can obtain the eddy diffusivity for $\mathrm{HNO}_{3}$ flux

$D=\frac{k u_{*}}{\ln \frac{z_{2}}{z_{1}}-\Psi_{H}\left(\frac{z_{2}}{L}\right)+\Psi_{H}\left(\frac{z_{1}}{L}\right)}$

$\overline{w^{\prime} c^{\prime}}=D \Delta Q$
Because the $\mathrm{HNO}_{3}$ measurements were conducted for long time periods (12-24 h) we computed a mean for the micrometeorological parameters and the $\mathrm{HNO}_{3}$ flux. The mean (efficacy) eddy diffusivity for the $\mathrm{HNO}_{3}$ flux is:

$\bar{D}=k \cdot \frac{u_{*}}{\ln \frac{z_{2}}{z_{1}}-\Psi_{H}\left(\frac{z_{2}}{L}\right)+\Psi_{H}\left(\frac{z_{1}}{L}\right)}$

and the mean period vertical $\mathrm{HNO}_{3}$ flux is equal to:

$\overline{w^{\prime} c^{\prime}}=\bar{D} \cdot\left[c\left(z_{1}\right)-c\left(z_{2}\right)\right]$

The surface fluxes were computed from the profile measurements using the flux gradient methodology. In order to validate this technique the results were compared with the eddy covariance technique applied to sonic anemometer data.

Acknowledgements. The authors would like to thank all the participants of the NICE experimental campaign, in particular Roberto Sparapani for the organization of NICE at Ny-Ålesund, Andrea Felici for his technical help, and Laura Ammiraglia, Elisabetta Colaiacomo, and Francesca DiBari for their tireless help in making the IC analyses of the denuder, filter and numerous snow samples. Thanks to Michel Legrand (CNRS - LGGE) for discussions on snow chemistry. Funding for this project was received from the European Commission (EVK2-1999-00029 'NICE'). The participation of FD to this campaign was funded by the French Polar Institute (IPEV).

\section{References}

Abbatt, J. P. D.: Interaction of $\mathrm{HNO}_{3}$ with water-ice surfaces at temperatures of the free troposphere, Geophys. Res. Lett., 24 1479-1482, 1997.

Allegrini, I., De Santis, F., Di Palo, V., Febo, A., Perrino, C., Possanzini, M., and Liberti, A.: Annular denuder method for sampling of atmospheric pollutants, Science of the Total Environ., 67, 1-16, 1987.

Beine, H. J., Honrath, R. E., Dominé, F., Simpson, W. R., and Fuentes, J. D.: $\mathrm{NO}_{\mathrm{x}}$ During Background and Ozone Depletion Periods at Alert: Fluxes Above the Snow Surface, J. Geophys. Res., 107 (D21), 4584, doi:10.1029/2002JD002082, 2002a.

Beine, H. J., Dominé, F., Simpson, W. R., Honrath, R. E., Sparapani, R., Zhou, X., and King, M.: Snow-Pile and Chamber Experiments During the Polar Sunrise Experiment 'Alert 2000': Exploration of Nitrogen Chemistry, Atmos. Environ., 36 (15/16), 2707-2719, 2002b.

Beine, H. J., Argentini, S., Maurizi, A., Mastrantonio, G., and Viola, A.: The local wind field at Ny-Ålesund and the Zeppelin mountain at Svalbard, Meteorol. Atmos. Phys., 78, 107-113, $2001 \mathrm{a}$.

Beine, H. J., Allegrini, I., Sparapani, R., Ianniello, A., and Valentini, F.: Three years of springtime trace gas and particle measurement at Ny-Ålesund, Svalbard, Atmos. Environ., 35 (21), 3645-3658, 2001b.

Beine, H. J. and Krognes, T.: The seasonal cycle of peroxyacetyl nitrate (PAN) in the Arctic, Atmos. Environ., 34 (6), 933-940, 2000.

Cabanes, A., Legagneux, L., and Dominé, F.: Evolution of the specific surface area and of crystal morphology of Arctic fresh snow during the ALERT 2000 campaign, Atmos. Environ., 36, 27672777, 2002. 
Dibb, J., Talbot, R., Munger, D., Jacob, D., and Fan S.-M.: Airsnow exchange of $\mathrm{HNO}_{3}$ and $\mathrm{NO}_{\mathrm{y}}$ at Summit, Greenland, J. Geophys. Res., 103, 3475-3486, 1998.

Dominé, F. and Shepson, P. B.: Air-Snow Interactions and atmospheric chemistry, Science, 297, 1506-1510, 2002.

Dominé, F., Cabanes, A., and Legagneux, L.: Structure, microphysics and surface area of the Arctic snowpack near Alert during the ALERT2000 campaign, Atmos. Environ., 36, 25732766, 2002.

Dubowski, Y., Colussi, A. J., and Hoffmann, M. R.: Nitrogen dioxide release in the $302 \mathrm{~nm}$ band photolysis of spray-frozen aqueous nitrate solutions: Atmospheric Implications, J. Phys. Chem., A, 105, 4928-4932, 2001

Fenter, F. F., Caloz, F., and Rossi, M.: Kinetics of nitric acid uptake by salt, J. Phys. Chem., 98, 9801-9810, 1994.

Ford, K. M., Shepson, P. B., Bertman, S. B., Honrath, R. E., Peterson, M., Dibb, J. E., and Bottenheim, J. W.: Studies of peroxyacetyl nitrate (PAN) and its interaction with the snowpack at Summit, Greenland, J. Geophys. Res., 107, ACH6, 2002.

Fuji, Y., Kohno, M., Motoyama, H., Matoba, S., Watanabe, O., Fujita, S., Azuma, N., Kikuchi, T., Fukuoka, T., and Suzuki, T.: Tephra layers in the Dome Fuji (Antarctica) deep ice core, Ann. Glaciol. 29, 126-130, 1999.

Hanisch, F. and Crowley, J. N.: Heterogeneous reactivity of gaseous nitric acid on $\mathrm{Al}_{2} \mathrm{O}_{3}, \mathrm{CaCO}_{3}$ and atmospheric dust samples: a Knudsen cell study, J. Phys. Chem., A, 105, 3096-3106, 2001.

Honrath, R. E., Lu, Y., Peterson, M. C., Dibb, J. E., Arsenault, M. A., Cullen, N. J., and Steffen, K.: Vertical fluxes of $\mathrm{NO}_{\mathrm{x}}, \mathrm{HONO}$ and $\mathrm{HNO}_{3}$ above the snowpack at Summit, Greenland, Atmos. Environ. 36, 2629-2640, 2002.

Honrath, R. E., Guo, S., Peterson, M. C., Dziobak, M. P., Dibb, J. E., and Arsenault, M. A.: Photochemical production of gasphase $\mathrm{NO}_{\mathrm{x}}$ from ice-crystal $\mathrm{NO}_{3}^{-}$, J. Geophys. Res., 105, $183-$ 190, 2000.

Honrath, R. E., Peterson, M. C., Guo, S., Dibb, J. E., Shepson, P. B., and Campbell, B.: Evidence of $\mathrm{NO}_{\mathrm{x}}$ production within or upon ice particles in the Greenland snowpack, Geophys. Res. Lett., 26, 695-698, 1999.

Ianniello A., Beine, H. J., Sparapani, R., Di Bari, F., Allegrini, I., and Fuentes, J.: Denuder measurements of gas and aerosol species above Arctic snow surfaces at Alert 2000, Atmos. Environ., 36 (34), 5299-5309, 2002.

Ianniello, A., Perrino, C., and Allegrini, I.: Operating manual for the annular denuder / filter pack sampling technique, C.N.R.-IIA, Rome, 50 pp., (Italian), November 1999.

Koop, T., Kapilashrami, A., Molina, L. T., and Molina, M. J.: Phase transitions of sea-salt/water mixtures at low temperatures: Implications for ozone chemistry in the polar marine boundary layer, J. Geophys. Res., 105, 26393-26402, 2000.

Mozurkewich, M.: The dissociation constant of ammonium nitrate and iyts dependence on temperature, relative humidity and particle size, Atmos. Environ., 27A, 261-270, 1993.

Nyeki, S., Coulson, G., Colbeck, I., Eleftheriadis, K., and Beine, H. J.: Overview of Aerosol Microphysics at Arctic Sunrise: Mea- surements during the NICE ReNO $\mathrm{x}_{\mathrm{x}}$ ification Study, Tellus, submitted, 2002.

Perrino, C., Ramirez, D., and Allegrini, I.: Monitoring acidic air pollutants near Rome by means of diffusion lines: development of a specific quality control procedure, Atmos. Environ., 35, 331-341, 2001.

Possanzini, M., Febo, A., and Liberti, A.: New design of a high performance denuder for the sampling of atmospheric pollutants, Atmos. Environ., 17, 2605-2610, 1983.

Prospero, J. M., Glaccum, R. A., and Nees, T.: Atmospheric transport of soil dust from Africa to South America, Nature, 289, 570 583, 1981

Ridley, B., Walega, J., Montzka, D., Grahek, F., Atlas, E., Flocke, F., Stroud, V., Deary, J., Gallant, A., Oudries, H., Bottenheim, J., Anlauf, K., Worthy, D., Sumner, A. L., Splawn, B., and Shepson, P.: Is the Arctic surface layer a source and sink of $\mathrm{NO}_{\mathrm{x}}$ in Winter/Spring? J. Atmos. Chem., 36, 1-22, 2000.

Rothlisberger, R., Hutterli, M. A., Sommer, S., Wolff, E. W., and Mulvaney, R.: Factors controlling nitrate in ice cores: evidence from the Dome C deep ice core, J. Geophys. Res., 105, 20565 $20572,2000$.

Rothlisberger, R., Hutterli, M. A., Wolff, E. W., Mulvaney, R., Fischer, H., Bigler, M., Goto-Azuma, K., Hanson, M. E., Ruth, U., Siggaard-Andersen, M.-L., and Steffensen, J. P.: Nitrate in Greenland and Antarctic ice cores: a detailed description of postdepositional processes, Ann. Glaciol., 35, in press, 2003.

Sozzi, R., Favaron, M., and Georgiadis, T.: Method for estimation of surface roughness and similarity function of wind speed vertical profile, J. Appl. Meteor., 37, 461-469, 1998.

Sozzi, R. and Favaron, M.: Sonic anemometry and thermometry: theoretical basis and data-processing software, Elsevier Science Ltd. 11, 4, 259-270, 1996.

Stull, R. B.: An introduction to boundary layer meteorology. Kluvert Academic Publishers, Dordrecht, Boston, London, pp. 666, 1988.

Stumm, W. and Morgan, J.J.: Aquatic Chemistry, WileyInterscience, New York, 1970.

Systat ${ }^{\circledR}$ 9, SPSS, Chicago, IL, USA, 1999.

Teinilä, K., Hillamo, R., Kerminen, V.-M., and Beine, H. J.: Aerosol chemistry during the NICE dark and light campaigns, Atmos. Environ., 37, 563-575, 2003.

Thibert, E. and Dominé, F.: Thermodynamics and kinetics of the solid solution of $\mathrm{HNO}_{3}$ in ice, J. Phys. Chem., B., 102, 44324439, 1998.

Zhou, X., Beine, H. J., Honrath, R. E., Fuentes, J. D., Simpson, W., Shepson, P. B., and Bottenheim, J.: Snowpack Photochemical Production as a Source for HONO in the Arctic Boundary Layer in Spring Time, Geophys. Res. Lett., 28 (21), 4087-4090, 2001.

Zhuang, H., Chan, C. K, Fang, M., and Wexler, A. S.: Formation of nitrate and non-sea-salt-sulfate on coarse particles, Atmos. Environ., 33, 4223-4233, 1999.

Zondlo, M. A., Barone, S. B., and Tolbert, M. A.: Uptake of $\mathrm{HNO}_{3}$ on ice under upper tropospheric conditions, Geophys. Res. Lett., 24, 1391-1394, 1997. 